\title{
Exploring Ideational Metafunction in Helon Habila's Oil on Water: A re-evaluation and redefinition of African Women's Personality and Identity through Literature
}

\author{
Léonard A. Koussouhon \\ Department of English, Faculty of Arts and Humanities (FLASH) \\ Université d'Abomey-Calavi, (UAC) Bénin \\ 01 P.O.Box 526, Cotonou \\ E-mail: koussouhon@yahoo.fr \\ Ashani M. Dossoumou (Corresponding author) \\ Laboratory for Research in Linguistics and Literature (LabReLL) \\ Faculty of Arts and Humanities (FLASH) \\ Université d'Abomey-Calavi, (UAC) Bénin \\ 05 P.O.Box 897, Place Lenine, Cotonou- BENIN \\ E-mail: dossoumoumichel@gmail.com
}

Received: 24-01- 2015

Published: 01-09- 2015
Accepted: 07-04- 2015

doi:10.7575/aiac.ijalel.v.4n.5p.129 URL: http://dx.doi.org/10.7575/aiac.ijalel.v.4n.5p.129

\begin{abstract}
This article aims at applying some of the principles guiding Systemic Functional Grammar (SFG) to Helon Habila's Oil On Water (2011). One of the major principles of Systemic Linguistics is that the exploration of the Transitivity properties (processes, participants, and circumstances) in/of a text can give a full insight into how the writer encodes experiential meaning therein (Koussouhon \& Allagbe, 2013 and Koussouhon \& Dossoumou, 2014). This implies that the analysis in/of a text can reveal how its language is organized to express the speaker's or narrator's personal experience, views, etc., thereby contributing to the meaning of personal and interpersonal interaction. Given the importance of social role played by language in any societal situation, the experiential meaning of a structural choice is not determined only by Lexico-grammar, but also by contextual factors (Gledhill, 2011). By applying the theory of the grammar of experiential meaning to Helon Habila's Oil On Water (2011), this article attempts to auscultate African society's emerging perception of gender identity as it affects and re-presents women. By borrowing the way the writer encodes his experience (or fictional reality) via the medium of language to affirm male writers' support to the trend, this article is proving the propriety and relevance of womanist theory by re-evaluating and re-defining African women's identity and personality through the novel under study.
\end{abstract}

Keywords: systemic functional grammar (SFG), experiential meaning, re-evaluation, redefinition, Womanism, women's identity

\section{Introduction}

One emerging reality in African literature and, in particular, African fiction, is the redefinition and / or re-presentation of African women's identity and personality. In the pioneering African literary fiction, women's identity was painted against the backdrop of the various societal schisms that seek to perpetuate the status quo of the enslaved female versus lionized male. But the advent and emergence of the third generation African women writers like Chimamanda Ngozi Adichie, Kaine Agary, Sefi Atta, Amma Darko and others, along with the influx of western pro-women ideologies like Gender mainstreaming, Feminism and Womanism, mark the inception of an era - that of the re-evaluation, redefinition and re-presentation of women's personality and identity. In this article which applies the grammar of experiential meaning to two extracts culled from Helon Habila's Oil On Water (2011), we attempt to revisit African society's perception of gender identity, mostly in the setting of the novel under study. More specifically, the inquiry will dig into the grammar of experiential meaning through its material, mental, relational, behavioural, verbal and existential processes. Eventually, the discussion of the linguistic findings resulting from the analyses will culminate in asserting that the redefinition of African women's personality and identity in African fiction is a timely endeavour that both African male and female writers of the new millennium should and must struggle to champion so as to revert the former unfavourable image and picture that some African and non-African fiction is used to portraying.

This article also aims at shedding the systemic functional grammar projector's light on how Helon Habila encodes journalistic experience through meanings to create, adopt and manage personal and interpersonal relations in the novel Oil On Water. 


\section{Theoretical background}

\subsection{A brief account of womanist theory}

Womanism is a woman-centered ideology derived from Feminism, which is a social movement viewing the male counterpart as primary enemy. Therefore, contrary to Feminism, the womanist theory is committed to the survival of the wholeness of the entire people including men. Womanism is, of course, an inclusive theory centered on the natural order of things in the nature, society, and family. According to Layli Phillips (2006), Womanism is a social change perspective rooted in Black women's and other women of colour's everyday experiences and everyday methods of problem solving in every spaces, extended to the problem of ending all forms of oppression, restoring the balance between people and environment/nature, and reconciling human life with the spiritual dimension. Emanating from the critical thinking ventured by Walker Alice in her Womanism, and two other authors, namely, Okonjo Ogunyemi with her perspective on African Womanism, and Hudson-Weems' Africana Womanism, this theory has come up with forming the collective basis for an interpolated field of theory and praxis used by a host of people to follow. Considering that Black women experience sexism, and Womanism being concerned with sexism, Feminism is confluent with the expression of Womanism, but Feminism and Womanism cannot be conflated, nor can it be said that Womanism is a "version" of Feminism. In spite of the speculations sprouting around womanist theory, its scholars and proponents contend that Womanism manifests five overarching characteristics: $1^{\circ}$ ) it is anti-oppressionist; $2^{\circ}$ ) it is vernacular; $3^{\circ}$ ) it is non-ideological; $4^{\circ}$ ) it is communitarian; and $5^{\circ}$ ) it is spiritualized. The non-ideological characteristic makes this theory be confluent with, and inclusively pliable to any theories, one of which is the Hallidayan theory.

\subsection{Defining the Ideational Metafunction}

The ideational metafunction is one of three metafunctions of language put forth by the now Australian (but former British) linguist MAK Halliday. The ideational function is encoded in the system of Transitivity. According to Halliday (1971: 354), the term Transitivity refers to:

the set of options whereby the speaker encodes his [or her] experience of the processes of the external world, and of the internal world of his [or her] own consciousness, together with the participants in these processes and their attendant circumstances; and it embodies a very basic distinction of processes into two types, those that are regarded as due to an external cause, an agency other than the person or object involved, and those that are not.

It is obvious from the above that the transitivity analysis of a fictional text explores how the authorial ideology is encoded therein. This function construes human experience through language, by making sense of "reality". It is viewed as a theory of reality and a resource for reflecting on the world. According to Halliday and Matthiessen (2006), it reflects the contextual value of "field" through participant, circumstance and process (material, mental, behavioural, relational, verbal and existential) types. The ideational metafunction encompasses two types of meaning- experiential and logical. This article only considers the Ideational metafunction through its transitivity pattern serving as a backdrop for the grammar of experiential meaning. Moreover, it analyzes all the six (06) process types summarized in Table 1 below.

Table 1. Processes with their related participants (adapted from Bloor and Bloor,

2004: 132) cited by Koussouhon and Koutchade (2012)

\begin{tabular}{ll}
\hline Material & Actor, Goal, Beneficiary, Range \\
\hline Mental & Senser, Phenomenon \\
\hline Relational & Carrier/attribute, Token/ Value, Possessor/Possessed \\
\hline Verbal & Sayer, Receiver, Verbiage \\
\hline Behavioural & Behaver, Behaviour \\
\hline Existential & Existent \\
\hline
\end{tabular}

\section{Transitivity analyses of the two extracts}

We carried out our transitivity analyses on two extracts drawn from Oil On Water (2011). Following Eggins (2004), Koussouhon and Allagbe (2013), Koussouhon and Koukpossi (2013), we first split and structured the extracts into clauses. Then we identified each process type in the extracts, counted and tabularized the findings accordingly (see details in appendices) for interpretation discussion.

The transitivity analysis of extracts No 1 and No 2 yielded the findings disaggregated and summarized in Table 2 below. 
Table 2. Disaggregated process types distribution in extracts no 1 and no 2

\begin{tabular}{|c|c|c|c|c|c|c|}
\hline \multicolumn{2}{|c|}{ Process types } & \multicolumn{2}{|c|}{ Extract No1 } & \multicolumn{2}{|c|}{ Extract No2 } & \multirow{2}{*}{$\begin{array}{c}\text { Process types in the } \\
\text { two extracts }\end{array}$} \\
\hline \multicolumn{2}{|l|}{ Material } & 76 & [43.18\%] & 91 & [47.64\%] & \\
\hline \multicolumn{2}{|l|}{ Mental } & 33 & [18.75\%] & 34 & $17.80 \%]$ & 67 [18.25\%] \\
\hline \multicolumn{2}{|l|}{ Behavioural } & 19 & [10. 79\%] & 17 & [08.90\%] & $36[09.80 \%]$ \\
\hline \multicolumn{2}{|l|}{ Verbal } & 13 & [07.38\%] & 15 & [07.85\%] & $28 \quad[07.63 \%]$ \\
\hline \multicolumn{2}{|l|}{ Existential } & 02 & [01.13\%] & 02 & [01.04\%] & 04 [01.08\%] \\
\hline \multirow{4}{*}{ Relationat } & Intensive Iden. & 29 & [16.47\%] & 28 & [14.65\%] & $57[15.53 \%]$ \\
\hline & Intensive Attr. & 00 & [00\%] & 00 & [00\%] & 00 [00 \%] \\
\hline & Circumstantial & 04 & [02.27\%] & 02 & [01.04\%] & 06 [01.63\%] \\
\hline & Possessive & 00 & [00\%] & 02 & [01.04\%] & 02 [0.54\%] \\
\hline \multicolumn{2}{|c|}{ Total processes } & 176 & {$[99.97 \%]$} & 191 & $100 \%$ & 367 [99.97\%] \\
\hline
\end{tabular}

\section{Critical Discussion of the findings}

As the transitivity analysis exudes, the two extracts contain three hundred and sixty-seven (367) processes. This figure is shared by the six process types propounded by Halliday and Matthiessen (2004). However, three out of the six, viz. Material processes (45.50\%), Mental (18.25\%), and Relational (17.71\%) processes sharing unequal proportions, are predominant. Apart from the existential processes that appear in very low (almost negligible) proportion (01.08\%), the other process types, viz, behavioural and verbal though ${ }^{2}$ appearing with less significant dominance with their varied proportions, respectively, $09.80 \%, 07.63 \%$ enhance this.

The preponderant number of material processes ( 167 out of 367 , making $45.50 \%$ ) in the two extracts indicates an overmaterialization in/of the text. This suggests that the extracts under study are about physical, concrete and tangible actions. That is to say, these extracts are highly materialized ones with mostly animate beings acting as actors and goals, ranges, recipients and clients. These animate beings are most of the time males and females, underpinning the fictional reality in/of the extract. It pinpoints the suffering of the Niger Delta, and non-Niger Delta people, Oil company executive, especially women, children as well as the newsmen on a fact-finding mission. That suffering has, in some cases, resulted into death. Furthermore, this intensive materialization insinuates that the setting depicted by the writer is a social and societal compendium, even though the number of female actors and goals sometimes exceeds that of their male counterparts; for instance, Mary's mother and sister have been beneficiaries of the process impregnated by one holy man, Rufus and Mary have been living as roommates in the same studio while attending the same school of journalism, Isaac and Isabel have been kidnapped together by the militants, Rufus and Ronke have attended the same school of journalism, Zaq and Ronke have worked for the same Journal etc., still the writer moves to restore an inclusive, social, and gender-balanced setting wherein physical, concrete and tangible actions are performed by the social actors and goals.

The analysis of the two extracts revealed 67 mental processes, making $18.25 \%$. All the characters performing in the extracts as Sensers are animate beings- male and female. They have been highlighted by the use of various and varied semantic representations- names, ad hoc description, and recoverable reference. This suggests that there are in these extracts some participants (senser, phenomenon) who are consciously, intellectually, affectively involved in the situation under description as it appears with the processes revealed in Extract no 1 in clauses 5 [saw], 12 [knew], 17 [noticed], 37 [watching], $71 \& 85$ [likes], 133 [wanted], containing such senser, animate beings (both males and females) as he, I, she, the community, she \& she, her mother. The participants acting as phenomena in those illustrative clauses are Zaq, Rufus, the Nurse, Mary referred to with the various semantic representations. As for Extract no 2, the exemplifying processes are: 19 [knew], 33 [believe], 53 [saw], 58 [died], 106 [seen], 114 \& 115 [nodded], 122 [hear], 152 [watching], including senser, animate beings (both males and females) like $I, I, h e$, my men, he, I, I \& she, we, I. The participants acting as phenomena in this extract are Rufus, Isabel, Isaac, Zaq, Isabel's husband. Both the participants performing and projecting conscious, intellectual, intelligible, affective actions as senser and those acting as phenomenon include male and female characters. This inclusive characterization adopted by the writer by focalizing the striking actions of the extracts under study, denotes a gender-balanced and inclusive society where varying roles are ascribed and assigned to women who feel and express the same intellectual, physiological, social, and affective needs as their male counterparts.

Following the logic of drawing on the past to build the present and properly project the future, Habila makes use of the identified 36 behavioural processes representing $09.80 \%$ along with the behavers, phenomenon, circumstantials and circumstances of occurrence. This denotes, like the mental processes, the fact that both extracts are concerned with the physiological and psychological needs of the participants. These fundamental needs are felt as a result of the lack of care and freedom imposed on the people as a whole by both the political leadership and oil companies. This low statistic 
figure indicates the depiction of contradictory practices performed by some behavers in the extracts. Let's consider for instance the following processes: knelt (clause No 15), stood (clause No 40), sat down (clause No 47) and sat (clause No 49) in Extract no 1 describing how unset the nurse has been while catering for the alcohol addict Zaq, whose physical and psychological capabilities have succumbed before the challenging fact-finding mission assigned to him. Coming to rescue Zaq medically, the nurse has, in fact, come to complement Rufus' effort. The focalisation of the above-mentioned processes no 15, 40, 47 and 49 on the nurse as behaver is insightful regarding the shift in African writers' characterisation of women in their fiction. This exudes, as advocated by womanist scholars, the complementarity of roles and relations between men and women in society. Moreover, the few number of behavioural processes also accounts for, and describes the social order of things in society, briefly from birth to death as it exudes in Extract no 2 through processes no 3 sat up, no 5 stood up and no 9 lain.

The depiction of social, physiological, educational and professional behavioural change ranges in the extracts ranges from the kidnapping, victimization of women through the impregnation of the mother and daughter by the same holy man, to the sending of the signal envelop calling for the negotiation for the possible release of Isabel. Considering female characters' victimization in the novel, it is exemplified by the fact that both mother and daughter have been impregnated by the same lionized and sex-maniac holy man. Indeed, this rape of African culture portrays the social structure in a male-dominated environment. This poor depiction and characterization of African women tally discriminatory comments such as: the woman is like a lifeless piece of property or thing that can be treated like lifeless object; the woman is senseless and incapable of logical reasoning, and as such, cannot partake in decision-making processes at home and in society at large; the woman should neither be seen, nor heard; the place of the woman in society is behind the burning firewood, the cooking pot, and ultimately in the bedroom. But against such discriminatory statements, beliefs, and constructs that set motherhood and procreation as the woman's major sources of fulfillment, contemporary African writers are moving to echoe the world by sounding their opposite clairon indicating new avenues for African women's self-fulfillment. They argue that it is untenable and unacceptable that womanhood is validated against such constructs. As a matter of fact, the nurse has not only fallen in love with Rufus, she has also struggled as much as possible to cater for, treat, and heal Zaq, even though she has not succeeded in achieving that.

The $09.80 \%$ behavioural processes can also be construed as indicative of the professional shift and upgrading in women character's professional movement. Mary has been shifting from simple TV journalist to a qualified specialist in news editing. As for Ms. Ronke, her professional behaviour and reality have shifted from the then simple journalist practised together with Zaq to the University lecturer. These striking depictions of African women's educational, social and professional paradigm shifts aid to re-evaluate and upgrade African women's vulnerable status to that of blossomed and fully-emancipated stakeholders, still besides their male counterparts.

The transitivity analysis of the two extracts revealed 28 verbal processes at the rate of $07.63 \%$. Here, while almost all the processes are imperative, the Sayer roles are performed by animate beings, mainly the militants' leader, the nurse, and other minor characters. As for the Receiver participants' roles, they are exclusively ascribed to Rufus and Zaq, both acting as Journalist and Reporter (The job of a journalist being that of playing the semantic role of receiver at its best), viz., receive the information, treat, process, transcribe it in a suitable format and convey it to the target public. The processes in both extracts are rather expressed in direct speeches. These comprise 07 negative, 03 interrogative negative, 01 positive interrogative, 06 imperative and 13 declarative. By scrutinizing, for instance, the declarative and imperative processes in the two Extracts, one realizes that they have two Sayers: the militants' leader (Professor) and the Nurse stating their mind and giving order to the two journalists. Zaq and Rufus, in the process of investigating about Isabel's kidnapping, have been ascribed the Receiver role by the writer. This subordinates the journalist and reporter to the other characters, namely, Isabel's husband, the Nurse, and Professor in the extracts. The journalists, reporters, and newsmen at large are sometimes biased while imparting information because at times, some Sayer uses their political, economic, financial, intellectual, and social power to influence the journalist to validate their idea. In all likelihood, these transitive patterns are indications of what the journalist is expected to provide in his / her written, oral and photographic reporting. Moreover, these processes are illustrative of the situation faced by journalists while doing their work. Beyond, this raises the eternal problem of the freedom of the press, opinion, and expression. The same patterns with their two (male and female) Sayers suggest the gender-balanced and equity advocated by the womanist scholars.

The transitivity analysis has revealed 65 relational including (57) intensive identifying, (04) circumstantial, and (02) possessive. This proportion of Relational processes in the extracts represents $22.43 \%$. This suggests and can be construed as an evidence of a gradual change of African writers' mentality and mindset, both male and female regarding the African woman's situation as depicted by the pioneer African writers. This change in the literary arena certainly depicts the new emerging relationships between men, women, and nature for the advent and realization of a balanced and fair treatment of the African woman by both contemporary male and female writers.

\section{Summary and conclusion}

This article has shed the systemic functional grammar projector's light on how Helon Habila encodes journalistic experience through meanings to create, adopt and manage a gender-balanced and womanist perspective in the novel Oil on Water. The lexico-grammatical analysis draws on the grammar of experiential meanings to explore the power of grammar (the powerhouse of language) at work to embed meanings. Thereafter, after a brief account of Womanism, an overview of the principles guiding the above-conducted ideational metafunction analysis has set the stage for the practical analysis of the two extracts under study. The interpretation and discussion of the SFL findings have actually 
come to second, with additional emphasis and a sharpening of focus, the findings of common sense. Ultimately, the application of the transitivity model to the analysis of this fictional text has demonstrated that ideational meaning is a useful tool for unraveling how a given text constructs its world, characters and actions in terms of who is doing what to whom, where, when, why and with what (Halliday and Matthiessen, 2004; Eggins, 2004). Indeed, Habila has chosen and applied the ideational metafunction (through experiential meaning) of language to construct and convey the individual's experience of the world, including the inner world of his own consciousness.

As for Helon Habila and his novel Oil On Water, the linguistic description and discussion of its salient features material, mental, behavioural, existential, verbal and relational processes, and the blend of extradiegetic narrative have served as a backdrop for this article to come up with the mind that the ideology sustaining this work is oriented towards restoring and championing the balance between men and women in African society. Moreover, one cannot overlook the fact that ideational, interpersonal and textual meanings are intimately inter-twined, therefore, the analysis of ideational meaning may well be combined with considerations about the two other types of meaning and discourse-semantics while carrying out the linguistic-stylistic analysis of a given text (Nørgaard, 2010). It follows from this to speculate (at discourse-semantic level) that the preponderant and profuse use of the definite article -deictic "the"- (82) and recoverable reference (Fontaine, 2013) through the pronouns "she, and her" (92) vs “he, him, his" (55) have all contributed to encode the womanist perspective in the fictional text. The idea propounded in this novel is essentially featuring social change through the exchange of meanings. So we can argue that the ideology sustaining Oil On Water is oriented towards building a redoubtable social propriety in a gender-balanced environment that will provide avenues for high-rocketing womanist movement. As only such a movement can ensure the re-evaluation and redefinition of African women's personality and identity throughout the depiction of their assigned roles. By focusing on ideational metafunction for the redefinition and re-presentation of African women's personality, ability and identity, this article has placed the Nigerian new millennium writer in a good position to reconstruct the African woman's past and present in proper perspectives to project the future of her image. In so doing, the author moves to sustaining and advancing the literary orientation geared by the fictional movement of redefinition, reshaping, restoration, and re-presentation of African women's personality, ability and identity. In this perspective, Helon Habila's novel has come as an unprecedented masculine support to Ngozi Chuma-Udeh's advocating position overtly expressed in her novel Echoes of a New Dawn (2007).

\section{References}

Achebe, Ch. (1958). Things Fall Apart. London: Heinemann Educational Books.

Amadi, E. (1966). The Concubine, ( $1^{\text {st }}$ ed.). London: Heinemann.

Ayoola, M. (2013). Interpersonal and Ideational Metafunctions of Some Selected Political Advertisements in Some Nigerian Newspapers. International Journal of Humanities and Social Science, 3(8).

Carter, R. A., \& Simpson, P. W. (2005). Language, Discourse and Literature: An Introductory Reader in Discourse Stylistics, ( $2^{\text {nd }}$ ed.). USA and Canada: Routledge.

Chuma-Udeh, N. (2007). Echoes of a New Dawn. Onitsha: Malchjay Nigeria Ltd.

Eggins, S. (2004). An Introduction to Systemic Functional Linguistics, (2nd ed.). Manchester, Great Britain: Continuum.

Fairclough, I., \& Fairclough, N. (2012). Political Discourse Analysis. USA and Canada: Routledge.

Fairclough, N. (2003). Analysing Discourse: Textual analysis for social research. London and New York: Routledge.

Fontaine, L. (2013). Analysing English Grammar: A Systemic Functional Introduction. New York: Cambridge University Press.

Gledhill, Ch. (2011). The 'lexicogrammar' approach to analyzing phraseology and Collocation. Asp No 59, pp 5-23.

Habila, H. (2011). Oil On Water, (1st ed.). New York: W.W. Norton \& Company, Inc.

Halliday, M.A.K., \& Matthiessen Ch. (2004). An Introduction to Functional Grammar, (3rd ed.). London: Hodder Education, and Hachette UK Company.

Halliday, M.A.K., \& Matthiessen Ch. (2006). Construing Experience Through Meaning: A Language-based Approach to Cognition. London - New York: Continuum.

Halliday, M. A. K (2009). Language and Society. London - New York: Continuum.

Halliday, M. A. K., \& Hasan, R. (1985). Language, context and text: aspect of language in a social- semiotic perspective. Oxford: Oxford University Press.

Halliday, M. A. K. (1971). Linguistic function and literary style: An inquiry into the language of William Golding's The Inheritors in S. B. Chatman (ed.) Literary Style, London and New York: Oxford University Press.

Hasan, R., \& Webster, J. J. (2005). Language, Society and Consciousness: The Collected Works of Ruqaiya Hasan Volume 1. London: Equinox Publishing Ltd.

Houghton, M. (1993). American Heritage College Dictionary $3^{\text {rd }}$ Indexed Edition. USA: Houghton Mifflin (T). 
Koussouhon, L., \& Dossoumou, A. (2014). Lexico-grammatical Analysis of Yellow-Yellow by Kaine Agary: Focus on Experiential and Textual Meanings. Mediterranean Journal of Social Sciences, 5(23), 2430-2438.

Koussouhon, L., \& Allagbe, A. (2013). The Lexicogrammar of Chimamanda Ngozi Adichie' fiction: A systemic functional contribution. In Langage \& Devenir No 22, $1^{\text {er }}$ semestre 2013, pp 19- 44.

Koussouhon, L., \& Koukpossi, A. (2013). Analyse lexico-grammaticale du discours d'investiture de François Hollande avec un accent spécial sur la transitivité. Revue Togolaise des Sciences, 7(1), 353-372.

Layli, Ph. (2006). The Womanist Reader. London and New York: Routledge

Nørgaard, N., et al. (2010). Key Terms in Stylistics. London and New York: Continuum.

Young, L., \& Harrison, C. (2004). Systemic Functional Linguistics and Critical Discourse Analysis, studies in social change. London and New York: Continuum.

\section{Lexico-grammatical analyses}

Keys: The Transitivity analysis has been carried out for each extract according to the keys presented below.

$\boldsymbol{P}=$ process; $\boldsymbol{P} \boldsymbol{m}=$ material; $\boldsymbol{P} \boldsymbol{m} \boldsymbol{e}=$ mental; $\boldsymbol{P b}=$ behavioural; $\boldsymbol{P} \boldsymbol{v}=$ verbal; $\boldsymbol{P} \boldsymbol{e}=$ existential $\boldsymbol{P} \boldsymbol{i}=$ intensive; $\boldsymbol{P c c}=$ circumstantial; $\boldsymbol{P} \boldsymbol{p}=$ possessive; $\boldsymbol{P} \boldsymbol{c}=$ causative; $\boldsymbol{A}=$ actor; $\boldsymbol{G}=$ goal; $\boldsymbol{B}=$ beneficiary; $\boldsymbol{R}=$ range; $\boldsymbol{S}=$ senser; $\boldsymbol{P} \boldsymbol{h}=$ phenomenon; $\boldsymbol{S y}=$ sayer; $\boldsymbol{R} \boldsymbol{v}=$ receiver; $\boldsymbol{V} \boldsymbol{b}=$ verbiage; $\boldsymbol{X}=$ existent; $\boldsymbol{T}=$ token; $\boldsymbol{V}=$ value; $\boldsymbol{C r}=$ carrier; $\boldsymbol{A t}=$ attribute; $\boldsymbol{P r}=$ possessor; $\boldsymbol{P} \boldsymbol{d}=$ possessed; $\boldsymbol{C}=$ circumstance; $\boldsymbol{C l}=$ location; $\boldsymbol{C} \boldsymbol{x}=$ extent; $\boldsymbol{C M}=$ manner; $\boldsymbol{C} \boldsymbol{c}=$ cause; $\boldsymbol{C a}=$ accompaniment; $\boldsymbol{C} \boldsymbol{t}=$ matter; $\boldsymbol{C o}=$ role; $\boldsymbol{A} \boldsymbol{g}=$ agent $\boldsymbol{B} \boldsymbol{e}=$ behaver; $\boldsymbol{B} \boldsymbol{h}=$ behavior.

\section{Extract 1: Pages 130 135}

1 We (A) found [Pm] 2 Zaq (A) seated (Pm) on his mat, (G) 3 facing (Pm) a fire (G) in a brazier (Cl) 2 that (G) had been placed $[\mathbf{P m}]$ near his feet $(\mathbf{C l})$. 3 His back (G) was propped [Pm] against the wall $(\mathbf{C l})$ 4 and his face (S) didn't change [PV] expression (Vb) 5 when he (S) saw [Pme] me (Ph) [[enter (Pm) with Gloria. (Ca)]] 6 He (Be) appeared lost in thought. [Pb]7 The nurse (Cr) is [Pcc] there (Cl) [[to see (Pme) you.(Ph)]]8 It (A) took [Pm] him (B) a few minutes (G) [[to look up (Pb), // sighing $(\mathbf{P b})$ heavily $(\mathrm{Cm})$ ]] 9 as he (A) did [Pm] so. 10 The flames (A) danced $[\mathbf{P m}]$ in the light and shadows on his face,(Cl) [[merging with (Pm) // and accentuating (Pm) the hollows and lines (G) on it (Cl). 11 His eyes (Cr) were [Pr:Int] shiny (At), 12 and I (S) knew[Pme] 13 that he (Cr) had been [Pr:Int] at [[ what (G) was left [Pm] of the bottle.]] 15 When (Cl) the nurse (A) knelt [Pb] before him 16 and took [Pm] his wrist (G) in her hand, (Cl) 17 she (S) noticed [Pme] it (Ph) too. 18 She (S) also saw [Pme] the bottle of whiskey (Ph) near his pillow (Cl). 19 She (A) reached forward [Pm] 20 and took [Pm] it (G).21 You (A)'ve been drinking [Pm]. 22 Your pulse (Cr) is [Pr:Int] very weak (At), 23 I (A) can't allow [Pm] you (G) to drink. (Pm) 24 And she (A) flung [Pm] the bottle at the open doorway, into the dark.(Cl) 25 To my surprise, Zaq (A) did not protest [Pm]. 26 He (Be) looked at $[\mathrm{Pb}]$ her $(\mathrm{Bh})$ with a fixed gaze. $(\mathrm{Ct})$ 27 Ah, nurse. ( $\mathrm{Vb})$ 28 You (Be) look [Pr:Int] great $(\mathrm{Pb})$ today $(\mathrm{Cl}) .29 \sim$ And you (Be) look [Pr:Int] drunk (Pb) today (Cl), Mr. Zaq.30 Rufus, Isn't [Pr:Int] she (Cr) very pretty (At)?31 The sternness (A) went out [Pm] of her face, (Cl) 32 and for a moment she (Cr) appeared [Pr] uncertain (At) 33 her hand (A) went [Pm] up [[to adjust (Pm) her scarf (G)]] - 34 and then she (Cr) became[Pi] serious (At) again. 35 I (A) went out $[\mathrm{Pm}]$ 36 and sat [Pm] on a tree trunk by the hut door (Cl). 37 From there I could see [Pme] the sculpture garden: the frozen community [[watching (Pme) the night, // warding off (Pm) evil, ears cocked for the night's watchword,1] 38 whatever that (Cr) might be [Pi]. 39 She (A) came out [Pm] 40 and stood [Pb] quietly $(\mathrm{Cm})$ beside me. 41 I (S) wanted [Pme] [[to talk [Pv] to her,]] 42 but there was [Pe] stillness (X) about her 43 that I (S) didn't want [Pme] to shatter. 44 At last she turned out [Pme] 45 and looked at (Pb) me.46 It (Cr)'s [Pr:Int] so peaceful (At) here, isn't[Pr:Int] it(Cr) ?47 She (Be) sat down [Pb lon the log (Cl) beside me, 48 and I (S) felt [Pme] the back of her hand brush against mine $(\mathrm{Ph})$ briefly $(\mathrm{Cm})$. 49 We $(\mathrm{Be})$ sat $[\mathrm{Pb}]$ in silence for a long time, [[watching (Pme) the darkness.]]50 It (T) is [Pr:Int] my fault (V). 51 I (A) brought [Pm] him (B) the drink. (G) 52 I (S) thought [Pme] 53 it (Be) would cheer [Pb] him up.53 You (A) didn't force [Pm] him (B) [[to drink (Pm) it (G).]] 54 He (Cr) 's [Pr:Int] old (At) enough [[to know[Pme]]] 55 what (Cr) 's [Pr:Int] good (At) for him (B).56 He (Cr) is[Pr:Int] a good man (V). 56 A great reporter. (Vb) 57 She (Sy) didn't say [Pv] anything (Vb) to that (Rv). 58 At last she (Be) stood up [Pb].59 I (A) have to go $[\mathrm{Pm}]$ now $(\mathrm{Cl})$. 60 My place in the village (Cr) is [Pcc ] near the jetty $(\mathrm{Cl})$. 61 You (A) must come [Pm] 62 and see [Pme] the jetty (Ph) 63 if you (Cr)'re [Pr:Int] still here (Cl) tomorrow. (C) 64 It (Cr) 's[Pr:Int] beautiful (At) in the evening (C) 65 when the boats (A) come in [Pm].66 I (A) will [Pm].67 She (A) left $[\mathrm{Pm}], 68 \sim$ and I (Be) watched after [Pb] her (Bh) 69 until (Cx) her shape (T) became[Pi] one with the night, invisible.(Ct) 70 I (S) think [Pme] 71 she (S) likes [Pme] you, Rufus, my friend.(Ph) 72 Zaq (A) had come out [Pm] onto the grass $(\mathrm{Cl})$ 73 and felt [Pme] around on his hands and knees (Ph) 74 till (Cx) he (A) found [Pm] his whiskey bottle (G). 75 Now (C) he (A) kept spitting [Pm] out bits of grass (G) 76 as he (A) took [Pm] long sips at the bottle.(G) 77 No, she (A) doesn't [Pm].78 She (S) likes [Pme] you (Ph). 79 Trust [Pb] me. 80 I (S) may not look [Pme] it (Ph), 81 but I (S) do know [Pme] about women $(\mathbf{C t})$. 82 I (S) saw [Pme] the way $(\mathbf{P h})$ 83 she (Be) was looking $[\mathrm{Pb}]$ at you. 84 No doubt about it. $(\mathrm{Vb})$ 85 She (S) likes [Pme] you (Ph). 86 You (A) 're not married (Pm), are [Pr:int] you (Cr)?87 No Not yet. (Vb) 88 Surely $(\mathrm{Cm})$ you $(\mathrm{A})$ must have [Pm] a girlfriend (G) back in Port Harcourt (Cl)?89 Look at [Pme] you, [[a very fine young man, (Cr)and being [Pr:Int] a journalist (V)]] 90 the girls (Cr) must be (Pcc) after you all the time.(Cl) 90 Well, not really (Cm). 91 I (Cr) 'm [Pr: Int] always (Cx) busy (At) with the job.(Ct) 92 There was[Pe] Mary (X), 93 whom I (A)'d met [Pm] at journalism school (Cl), 94 but I (Sy) didn't tell [PV] him (Rv) about that. 95 Mary (S) wanted [Pme] so badly (Cm) to get married (Pm). 96 She (Ag) had made $[\mathrm{Pm}]$ all the plans, (G) 97 and at night she (A)'d go $[\mathrm{Pm}]$ over them $(\mathrm{G})$ with me $(\mathrm{Ca})$ in the little room $(\mathrm{Cl})$ 98 we (A) shared [Pm] not far from the campus.(Cl) 99 It (Cr) was[Pr:Int] a tenement house, a face $\sim$ me $\sim$ Iface you.(V) 100 I (A) moved in [Pm] with her a shirt, a brush, a shoe at a time (Ct). 101 It (Cr) was [Pr:Int] cheaper (At) 102 if we (A) stayed [Pm] together, 103 she (Sy) said [Pv]. 104 Looking back,(Cm) I (S) guess[Pme] 105 she 
(A) must have started planning to marry $[\mathrm{Pm}]$ me (B) from the first day (Cl) 106 we (A) met [Pm]. 107 She (T) was [Pr:Int] that kind of girl (V). 108 Forward looking. (Cm) 109 She (Cr) was [Pr:Int] a TV journalist (V) 110 and her employers (A) had sent [Pm] her (B) to the journalism school (Cl) [[to specialize (Pm) in news editing (G).]] 112 Sometimes, (Cx) she (A)'d go away [Pm] for the weekend (Cl), 113 and I (S) knew [Pme] 114 she (Cr) was away [Pr:Int] with her old boyfriend (Ca) from her office.(Cl) 115 She (Sy) never talked [Pv] about him, 116 and I (Sy) never asked [PV] her 107 why would I, [[ since I didn't really love[Pme] her]]? 119 She (Cr) was [Pr:Int] pretty and clever (At) 120 and the sex (Cr) was[Pr:Int] good (At), 121 but I(S) didn't see [Pme] myself [[spending (Pm) the rest of my life (G) with her.(Ca) 122 Whenever she (A) came back [Pm] from her little trips (Cl) 123 she (A) 'd hold [Pm] me (B) all night long, tight, (C) [[sometimes (Cx) crying [Pb] // to show how much // she (S) 'd missed [Pme] me.]] 125 Once, (Cx) she (A) went [Pm] to Ibadan (Cl) [[ to visit her parents,]] 125 and when (C) she (A) came[Pm] back 126 she (A) had changed [Pm]. 127 She (Cr) was [Pr:Int] scared (At), 128 and for two nights (C) she (S) didn't sleep [Pme]. 129 When (C) I (Sy) asked [Pv] her (Rv) 130 what (Cr) was [Pr:Int] wrong (At), 131 she told [Pv] me (Rv) about the holy man (Vb). 132 Her father (A) had died [Pme] many years back, (C) 133 and her mother (S) wanted [Pme] to remarry (Pm) 134 but wasn't having [Pp] any luck, (Pd) 135 and so she (Sy) asked [PV] a holy man (Rv) [[to pray [PV] for her (Rv)]]. 136 He (A) moved [Pm] into the guest room (Cl), 137 and then one day (Cl) Mary (A) came [Pm] home (Cl) to find (Pm) 138 he (A)'d moved [Pm] into her mother's bedroom (Cl), 139 and had impregnated [Pm] not only her mother but also her seventeen year old sister.(G) 140 She (A) went [Pm] to the police, $(\mathbf{C l})$ 141 but her mother (A) refused to back $[\mathbf{P m}]$ her (G) up, 142 and her sister (Be) was terrified (Pb) [[and confused $(\mathbf{P b})$ ]] 143 and didn't know [Pme] whom to support (Pm), 144 and all the while (C) the holy man (Cr) was [PCc] there in the background,(Cl) 145 not saying [Pv] a word, [[clutching (Pm) his Bible, (G) // taking (Pm) the name of God in vain (G)]. 145 And she (A) had left [Pm]. 146 She (A) gave up[Pm]. 147 She (A) held [Pm] me (G) tight $(\mathrm{Cm})$, 148 till I (Be) couldn't breathe [Pb], 149 sobbing, $(\mathrm{Pb})$ 150 I (Pr) don't have [Pp] a family anymore,(Pd) 150 you (T) are [Pr: int] all (V) [[I (Pr) have (Pp). 151 Promise [Pm] me (B) 152 you (Cr) 'll be [Pcc] with me (Ca) always.(Cx)] 153 But I (Sy) didn't tell [Pv] Zaq any of this (Rv) 154 My last girlfriend (S) wanted to get married [Pm], 155 but I (A) wasn't [Pr:Int] ready (At). 156 We (Cr) were [Pr:Int] too young (At). 157 we (Cr) were (Pi) Twenty three, both of us.(V) 158 She (S) wanted [Pme] us (Ph) to run away (Pm) to Abuja 159 and start $(\mathrm{Pm})$ a life together $(\mathrm{G})$. 160 Alone. $(\mathrm{Cm})$ 159 Away from family and friends. $(\mathrm{Cm})$ 160 No. (Vb) 161 She (Cr) was [Pr:Int] wrong, and selfish (At). 161 You (A) can't run (Pm) from your family.(Cl) 162 It (Cr)'s[Pr:Int] not right.(At)

\section{Extract 2: Pages 229 232}

1 When (C) I (Be) woke up [Pb] the next morning (Cl) 2 a man (Be) was kneeling [Pb] over me, 3 nudging [Pm] me (B) with his gun. (Ct) 3 I (Be) sat up [Pb] quickly (Cm) 4 and the man (Be) stood up [Pb] 5 and moved back [Pm]. 6 The others (Cr) were [Pr:Int] awake, (At) except Salomon, 7 who (Cr) wasn't [Pcc] anywhere (Cl) [[to be seen [Pme].]] 8 After our interview (C) he (Be) had turned [Pb] away from me 9 and lain [Pb] on his side (Cl), 10 and he $(\mathrm{Be})$ hadn't gotten up [Pb] even 11 when $(\mathrm{C})$ our evening meal (G) was brought [Pm] by the same group (A) 12 that (A) had fed [Pm] us (B) earlier. 13 When (C) I (A) called [Pm] to him [[to come (Pm)// and eat,]] 14 he (Sy) had said [PV] no, (Vb) 15 he (Cr) wasn't [Pr:Int] hungry (At). 16 Now (C) the man with the gun (Be) beckoned [Pb] to me with one hand $(\mathbf{C t})$ 17 and turned $[\mathrm{Pb}]$ 18 and started [Pm] towards the trees. (Cl) 19 For some reason I (S) knew [Pme] 20 I (G) was being taken [Pm] to the Professor, 21 and I (Cr) was [Pr:Int] ready (At). 22 In the time (C) I (Cr) had been[Pr:Int] here (Cl) 23 I (A) had somehow managed (Pm) [[to get over (Pb) my initial fear and nervousness, (Bh) 24 and had finally $(\mathbf{C m})$ come $[\mathrm{Pm}]$ to believe [Pme] 24 what $(\mathbf{P h}) /(\mathrm{Cr})$ [/ I (S) always knew[Pme] in my heart (Cl)]] was [Pr:Int] true (At) 24 and yet had never taken [Pm] consolation(G) in (Cl) 25 the Professor (S) needed [Pme] the press (Ph), 26 and from all that I (S) had heard [Pme] about him (Ph), 27 he (Cr) wasn't [Pr:Int] a madman (At) 28 who (A) shot [Pm] people (B) for fun. 29 He (Cr) was [Pr:Int] a man (At) with an agenda (Ct), 30 and anything that (A) could help [Pm] him in that pursuit $(\mathrm{Cm}) 31 \sim$ he $(\boldsymbol{A})$ 'd treat $(\mathbf{P m})$ with respect $(\mathrm{Cm})$.32 I (T) was [Pr:Int] that thing (V) , 33 and the more firmly (Cm) I (S) believed [Pme] that (Ph), 34 and behaved [Pb] accordingly $(\mathrm{Cm}), 35 \sim$ the safer $(\mathrm{Cm})$ I $(\mathrm{Cr})$ would be [Pr:Int].36 The Professor (Be) was lying [Pb] in a hammock (Cl) [[hanging (Pm) from two stunted mango trees,]] 37 and he (A) jumped down [Pm] 38 as soon as (Cx) I (G) was presented [Pm] to him.(B) 39 There were [Pe] about a dozen men around him, (X) 40 all (G) armed [Pm], 41 all (Be) looking $[\mathbf{P b}]$ distrustfully at me (Bh). 42 Above us, through the tree branches, (Cl) I (S) could see [Pme] the sun (Ph) [[just breaking out [Pm] of the eastern clouds.]] 43 Most of the camp (Cr) was [Pr] still asleep (At).44 Journalist, it (C) is [Pr:Int] a pity (V) about your friend .45 My friend? (Vb) 46 The white woman's driver.(Vb) 47 Didn't they (Sy) tell [Pv] you (Rv)? 48 Didn't anyone (Sy) tell [Pv] you (Rv)? 49 He (A) tried to run away (Pm) early this morning $(\mathbf{C m})$. 50 He (A) had done [Pm] it (G) once, $(\mathbf{C x})$ 51 and he (S) thought [Pme] 51 it (Cr) was going to be $(\mathbf{P i})$ as easy as before $(\mathrm{Cm}), 52 \sim$ but you $(\mathbf{B e})$ can't fool $[\mathbf{P b}]$ the people (Bh) all the time (C). 53 My men (S) saw [Pme] him (Ph) 54 and gave [Pm] chase (G) 55 and he (A) lost [Pm] his head.(G) 56 He (A) jumped off [Pm] the cliff (G) 57 and fell [Pm] on the rocks below (G). 58 He (S) died [Pme] instantly. (Cm) 59 I (A) closed [Pm] my eyes (G) .60 His body (G) was taken away [Pm] by the river.(A) 61 A tragedy, don't you (S) think [Pme]? 62 I(S) find [Pme] it (Ph) hard [[to believe[Pme]...]] 63 The Professor (A) stepped [Pm] forward 64 till he (Be) was standing [Pb] right on front of me $(\mathrm{Cl}), 65 \sim$ but the menace of his gesture $(\mathrm{G})$ was diminished $[\mathrm{Pm}]$ by his short stature (A) 66 his eyes $(\mathbf{C r})$ were $[\mathbf{P C C}$ just about level $(\mathbf{C l})$ with my chin $(\mathbf{C t})$. 67 Two of his men (A) stepped [Pm] forward with him (Ca), 68 and their combined presence (A) forced [Pm] me (B) [[to take (Pm) a step (G) back,]] 69 and yet I (S) felt [Pme] no fear.70 Are you (A) calling [Pm] me (B) a liar, reporter? 71 No, Professor, (Vb) 72 I (Cr) am [Pr:Int] not. 72 I (S) don't know [Pme] you (Ph) well enough [[to do (Pm) that (G).]] 73 He (Be) looked [Pb] at me (Bh) for a while,(C) 74 and then he (Be) turned [Pb] 75 and hopped [Pm] back into his hammock,(G) 76 his short legs (A) swinging (Pm), 77 his thick military boots (A) clicking together (Pm), [[dropping (Pm) bits of mud (G) into the grass. (C1)]] 76 He (A) extended [Pm] his arm (G) 77 and one of the men (A) placed [Pm] a rifle (G) into the open hand $(\mathbf{C l}) .78 \sim$ You reporters, you (Cr) are [Pr:Int] always clever (At) with words (Ct) 79 me, I (Cr) am [Pr:Int] a soldier (At), 80 I (S) know [Pme] how to fight (Pm), 81 and I (A) still never stop fighting [Pm] 82 till I (A) achieve [Pm] my goal.(G) 83 Write [Pm] that when (C) you (A) get back [Pm].83 I (A) will do [Pm] that.(G) 84 I (Sy) called [Pv] you (Rv) here $(\mathrm{Cl})$ [[to set $[\mathrm{Pm}]$ you (B) free]]. 85 You (A) can go [Pm]. 86 There is $[\mathrm{Pe}]$ a boat (X) [[ waiting (Pm) for you (B).]] 87 One of my men (A) will take [Pm] you (B) to a nearby village (Cl) 88 and you (Cr) will be 
[Pp] on your own (Pd). 89 We (A) are going out $[\mathbf{P m}]$ on an operation (G); 90 you (S) may have noticed [Pme] the whole camp (Ph) [[ getting [Pr:Int] ready (At)]]. 91 By this time tomorrow (C), one of the major oil depots (A) will be burning [Pm]. 92 I (S) want [Pme] you (Ph) [[to write (Pm) about it (Ct)]], 93 tell [Pv] them (Rv) 94 I (Cr) am [Pr:Int] responsible (At) (Iden). 95 I (Sy) can't tell [Pv] you (Rv) more than that,(Vb) 96 but I (Sy) can tell [Pv] you (Rv) 97 the war (A) is just starting [Pm]. 98 We (A) will make [Pm] it so hot for the government and the oil companies 99 that they will be forced [Pme] to pull out [Pme]. 100 That is [Pr:Int] all 100a I can say [Pv]for now).101 What about the woman?102 The woman is [Pr:Int] safe (Attr:), 103 as you will see [Pme] for yourself.104 There was[Pe] a movement behind the trees 105 and two men appeared [Pme], leading Isabel. 106 She looked [Pr:Int](106a as I had last seen [Pme] her (Ph)), still wearing the same clothes, 107 her hair (A) shockingly $(\mathbf{C m})$ cropped [Pm] short, 108 but in her posture and in her gaze (Cl) I (S) detected [Pme] a subtle change, a sort of resignation, a surrender to the strange and obscure forces (Ph) 109 that (A) sometimes $(\mathbf{C x})$ take over [Pm] our lives (G), 109 and which it (Cr) is [Pr:Int] futile (At) to resist.(Pm) 110 I (Ag) made [Pc] to go (Pm) toward her (B) 111 but one of the men (A) raised [Pm] his gun (G) 112 and shook [Pm] his head (G) at me (B). 113 My eyes (A) met [Pm] hers (G) 114 and I (S) nodded [Pme],115 and she (S) nodded,[Pme] 116 then she (S) turned[Pme] [[and was led away[Pm] by the men (A).]]118 Take [Pm] this envelope (G) to her husband (B): 119 it (A) contains [Pm] more of her hair (G). 120 Tell [PV] him (Rv) 121 his (Cr) wife is [Pr:Int] safe (At), 122 but after two days (C), if we (S) don't hear [Pme] from him (Ph), 123 we (A) can't guarantee [Pm] her safety (G) anymore. 124 We (Cr) are getting [Pr:int] impatient (At). 125 Two days, final. (Vb) 126 There is [Pe] another woman (X), from Irikefe (Cl). 127 Her name (T) is [Pr:Int] Gloria (V). 128 Your men (A) took [Pm] her (B) a few days ago (C)...129 Ah, the nurse. (Vb) 130 She (A) is gone [Pm]. 131 We (A) set [Pm] her (B) free two days ago (C). 132 Did you (S) think [Pme] 133 we (A)'d keep [Pm] her (B) here (Cl) against her wish (G), 134 rape [Pm] her, (B) 135 maybe? 135 We (Cr) are not [Pr:Int] the barbarians (V) 136 the government propagandists (S) say [PV] 137 we (Cr) are[Pr:Int]. 137 We (Cr) are [Pr:Int] for the people (B). 138 Everything (Cr) [[we (A) do (Pm)]] is [Pr:Int] for the people (B), 139 what (G) will we (A) gain [Pm] 140 if we (A) terrorize [Pm] them (B)? 141 I (Sy) am speaking [PV] for myself and my group, (Rv) of course. 142 I (Cr) am [Pr:Int] aware [At] that, out there (Cl), 143 there are [Pe] criminal elements (X) 143 looting (Pm) 144 and killing (Pm) under the guise of freedom fighting, (Cl) 144 but we (Cr) are [Pr:Int] different (At). 145 Those kind of rebels, they (T) are [Pr:Int] our enemies (V). 146 That (Cr) is [Pr] why 147 I (A) am letting [Pm] [lyou (A) go (Pm)]], 148 so you (A) can write [Pm] the truth (G). 149 And be careful, (Vb) 150 whatever (G) you (A) write [Pm], 151 be careful.(Vb) 152 I (S) am watching [Pme] you (Ph). 153 I (Pr) have [Pp] people (Pd) everywhere (Cl).154 I (A) will write [Pm] only the truth (G).155 He (A) jumped down [Pm] 156 and came forward [Pm] 157 till his chin (A) was[Pr:Int] almost touching (Pm) my chest (G). 157 This time $(\mathbf{C})$ he $(\mathbf{A})$ reached $[\mathbf{P m}]$ out a finger $(\mathrm{Cl})$ 158 and poked [Pm] me (B), 159 his eyes (A) locked [Pm] with mine $(\mathrm{Ct}) .160 \sim$ Write $[\mathrm{Pm}]$ only the truth (G). 161 Tell [PV] them (Rv) about the flares 162 you (S) see [Pme] at night, (Cl) and the oil on the water (Ph). 163 And the soldiers (A) forcing (Pm) us (B) [[to escalate (Pm) the violence (G) every day (Cl)]]. 164 Tell [PV] them (Rv) 165 how we (A) are hounded [Pm] daily (Cx) in our own land (Cl). 166 Where (Cl) do they (A) want [Pme] us (Ph) to go (Pm), 167 tell [Pv] me, (Rv) where (Cl)? 168 Tell [Pv] them (Rv) 169 we (A) are going [Pm] nowhere (Cl) 170 This land (Pd) belongs [Pp] to us (Pr). 171 That (Cr) is [Pr:Int] the truth (V), 172 remember [Pme] that (Ph). 173 You (A) can go [Pm]. 